Article

\title{
A Lactose-Binding Lectin from the Marine Sponge Cinachyrella Apion (Cal) Induces Cell Death in Human Cervical Adenocarcinoma Cells
}

\author{
Luciana Rabelo ${ }^{1}$, Norberto Monteiro ${ }^{1}$, Raphael Serquiz ${ }^{1}$, Paula Santos ${ }^{1}$, Ruth Oliveira ${ }^{1}$, \\ Adeliana Oliveira ${ }^{1}$, Hugo Rocha ${ }^{1}$, Ana Heloneida Morais ${ }^{2}$, Adriana Uchoa ${ }^{3}$ and Elizeu Santos ${ }^{1, *}$ \\ 1 Department of Biochemistry, Federal University of Rio Grande do Norte, Natal, RN, 59072-970, \\ Brazil; E-Mails: luciana_marabelo@hotmail.com (L.R.); norbertokv@gmail.com (N.M.); \\ raphaserquiz@hotmail.com (R.S.); paulaims@gmail.com (P.S.); richeledbq@gmail.com (R.O.); \\ cisteana@yahoo.com.br (A.O.); hugo-alexandre@uol.com.br (H.R.) \\ 2 Department of Nutrition, Federal University of Rio Grande do Norte, Natal, RN, 59072-970, Brazil; \\ E-Mail: aharaujomorais@gmail.com \\ 3 Department of Cellular Biology and Genetic, Federal University of Rio Grande do Norte, Natal, \\ RN, 59072-970, Brazil; E-Mail: afuchoa2003@yahoo.com.br
}

* Author to whom correspondence should be addressed; E-Mail: elizeu@ufrnet.br; Tel.: +55-84-32153416, Fax: +55-84-32119208.

Received: 6 January 2012; in revised form: 23 February 2012 / Accepted: 5 March 2012 / Published: 28 March 2012

\begin{abstract}
Cancer represents a set of more than 100 diseases, including malignant tumors from different locations. Strategies inducing differentiation have had limited success in the treatment of established cancers. Marine sponges are a biological reservoir of bioactive molecules, especially lectins. Several animal and plant lectins were purified with antitumor activity, mitogenic, anti-inflammatory and antiviral, but there are few reports in the literature describing the mechanism of action of lectins purified from marine sponges to induce apoptosis in human tumor cells. In this work, a lectin purified from the marine sponge Cinachyrella apion $(\mathrm{CaL})$ was evaluated with respect to its hemolytic, cytotoxic and antiproliferative properties, besides the ability to induce cell death in tumor cells. The antiproliferative activity of CaL was tested against HeLa, PC3 and 3T3 cell lines, with highest growth inhibition for HeLa, reducing cell growth at a dose dependent manner $(0.5-10 \mu \mathrm{g} / \mathrm{mL})$. Hemolytic activity and toxicity against peripheral blood cells were tested using the concentration of $\mathrm{IC}_{50}(10 \mu \mathrm{g} / \mathrm{mL})$ for both trials and twice the $\mathrm{IC}_{50}$ for analysis in flow cytometry, indicating that $\mathrm{CaL}$ is not toxic to these cells. To assess the
\end{abstract}


mechanism of cell death caused by CaL in HeLa cells, we performed flow cytometry and western blotting. Results showed that lectin probably induces cell death by apoptosis activation by pro-apoptotic protein Bax, promoting mitochondrial membrane permeabilization, cell cycle arrest in $\mathrm{S}$ phase and acting as both dependent and/or independent of caspases pathway. These results indicate the potential of $\mathrm{CaL}$ in studies of medicine for treating cancer.

Keywords: HeLa; lectin; antitumor; marine sponge; Cinachyrella apion

\section{Introduction}

Cancer develops due to failures in the mechanisms that normally control cell growth and proliferation. Therefore, losses in the regulation of these cells are, in most cases, caused by genetic damage [1]. Cervical cancer, or cervix cancer, stand out among female genital tract neoplasms, the second most common cancer among women worldwide. With approximately 500,000 new cases per year worldwide, cervical cancer is responsible for the deaths of approximately 230,000 women per year. Conventional cancer treatment can be done in several ways: surgery, radiotherapy, chemotherapy, or in some cases, it is necessary to combine more than one method for treating the cancer. Several distinct biological strategies might prove effective in eliminating established tumors or preventing the maintenance of its progression. The most obvious are designed to induce cancer cell death via apoptosis [2]. Because of the high specificity of interactions with carbohydrates, lectins can serve as marker molecules to specific tumor cell glycoconjugates. In addition, they can be conjugated to a range of carrier agents, acting specifically in malignant cells. In marine invertebrates, most lectins found belong to the family of calcium dependent lectins (C-type lectins), obtained from organisms of different phyla: arthropoda (Tachypleus tridentatus), mollusca (Mytilus edulis), echinodermata (Anthocidaris crassispina, Cucumaria echinata) and others [3-6]. There are few studies in the literature linking properties of lectins from marine sponges with cytotoxic effects or induction of apoptosis in malignant cell lines [7-11]. Our research group purified and characterized a lectin from the marine sponge Cliona varians $(\mathrm{CvL})$ [12], with potential antitumor activity on $\mathrm{K} 562$ cells (chronic myelogenous leukemia). After the induction of cell death by $\mathrm{CvL}$, the appearance of nuclei with different levels of chromatin condensation and nuclear fragmentation was observed, as well as quantification of apoptotic cells by flow cytometry analysis $(43 \pm 5 \%$ of the total cell population in the apoptotic stage, $p<0.05$ ), triggering the release of cathepsin $\mathrm{B}$ of vesicular compartments within the cytoplasm with subsequent translocation into the nucleus, without affecting cell viability of normal lymphocytes from human peripheral blood at the same concentrations tested. We have recently purified and characterized a lectin from the marine sponge Cinachyrella apion, denominated CaL, which presents strong hemagglutinating activity with preference for papainized type A erythrocytes [6]. The hemagglutinating activity is independent of bivalent ions, and it was strongly inhibited by disaccharide lactose. $\mathrm{CaL}$ was heat-stable between 0 and $60{ }^{\circ} \mathrm{C}$ and $\mathrm{pH}$-stable. The lectin has a molecular mass of $124 \mathrm{kDa}$, consisting of eight subunits of $15.5 \mathrm{kDa}$, assembled by non-covalent interactions. CaL also agglutinated Leishmania chagasi promastigotes, and this activity was arrested by lactose. In this 
work, we show that $\mathrm{CaL}$ inhibits proliferation of cultured tumor cell lineage by the induction of cell death.

\section{Results}

\subsection{Effects of CaL on Cell Proliferation of Tumor Cells Lines}

The cytotoxicity of CaL to HeLa, PC3 and 3T3 cells was investigated after an incubation period of 24 and $48 \mathrm{~h}$ using the colorimetric MTT assay (Figure 1). HeLa and PC3 cell proliferation were inhibited in a dose-dependent manner in response to increasing concentrations of CaL $(0.5-10 \mu \mathrm{g} / \mathrm{mL})$. CaL also presented toxicity against 3T3 cells, although it had low significance in comparison to the other cell lines tested. HeLa cells had a greater inhibition rate after $\mathrm{CaL}$ treatment, so this lineage was used in further tests. The $50 \%$ inhibition $\left(\mathrm{IC}_{50}\right)$ was obtained with a concentration of $10 \mu \mathrm{g} / \mathrm{mL}$ of CaL, confirmed with an independent experiment using $20 \mu \mathrm{g} / \mathrm{mL}$ of CaL as a final concentration (Figure 2), a dose that inhibited around $95 \%$ of $\mathrm{HeLa}$ cell proliferation. Pre-incubation of $\mathrm{CaL}$ with lactose reduced significantly its antiproliferative activity on the HeLa cell (Figures 1 and 2), indicating that there may be a close link between the lectin-active domain and its antiproliferative activity.

Figure 1. Effect of CaL on viability of cell lines PC3, 3T3 and HeLa. The cytotoxicity of $\mathrm{CaL}$ on the tumor lines PC3 and HeLa and against the normal mouse fibroblast 3T3 line was performed by MTT reduction assay. The test cells were treated with different concentrations of CaL $(0.5-10 \mu \mathrm{g} / \mathrm{mL})$ for 24 and $48 \mathrm{~h}$ of culture in microplates. CaL $(10 \mu \mathrm{g} / \mathrm{mL})$ incubated with specific inhibitor lactose $(0.1 \mathrm{M})$ was used. The viability of cells treated with $\mathrm{CaL}$ was expressed as a percentage of the viability of untreated control cells. Results represent the mean $\pm \mathrm{SD}$ (standard deviation) of three experiments run in three replicates. *** $p<0.001$ compared to control (Student-Newman-Keuls test).

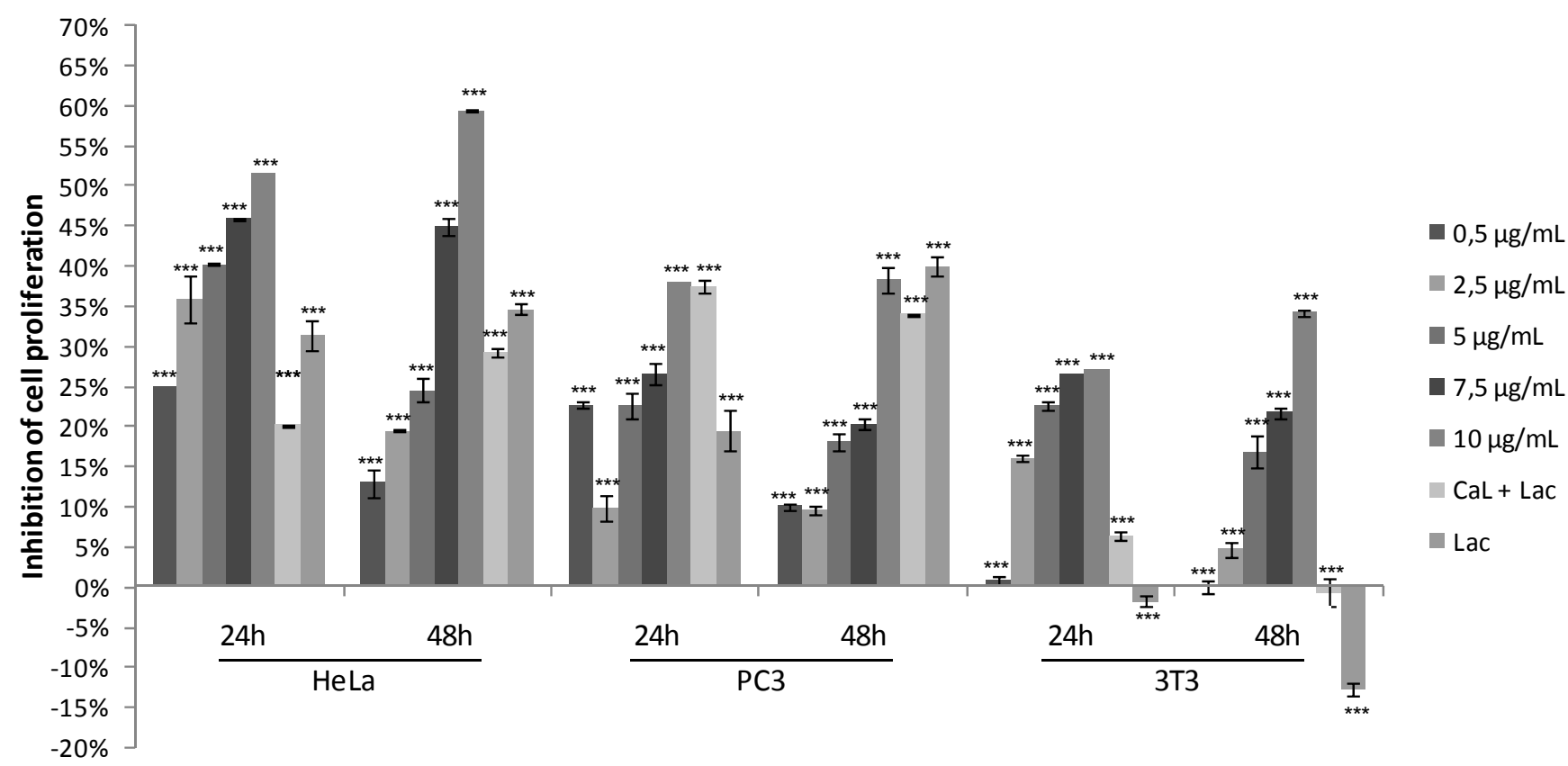


Figure 2. Cytotoxicity of $\mathrm{CaL}$ on $\mathrm{HeLa}$ tumor strain. HeLa cells were incubated with different concentrations of CaL until twice the $\mathrm{IC}_{50}(20 \mu \mathrm{g} / \mathrm{mL})$ for $48 \mathrm{~h}$, and the cell proliferation was evaluated and compared with untreated control cells. CaL $(20 \mu \mathrm{g} / \mathrm{mL})$ pre-incubated with lactose and only lactose was also tested. Results represent the mean \pm SD of three experiments run in three replicates.

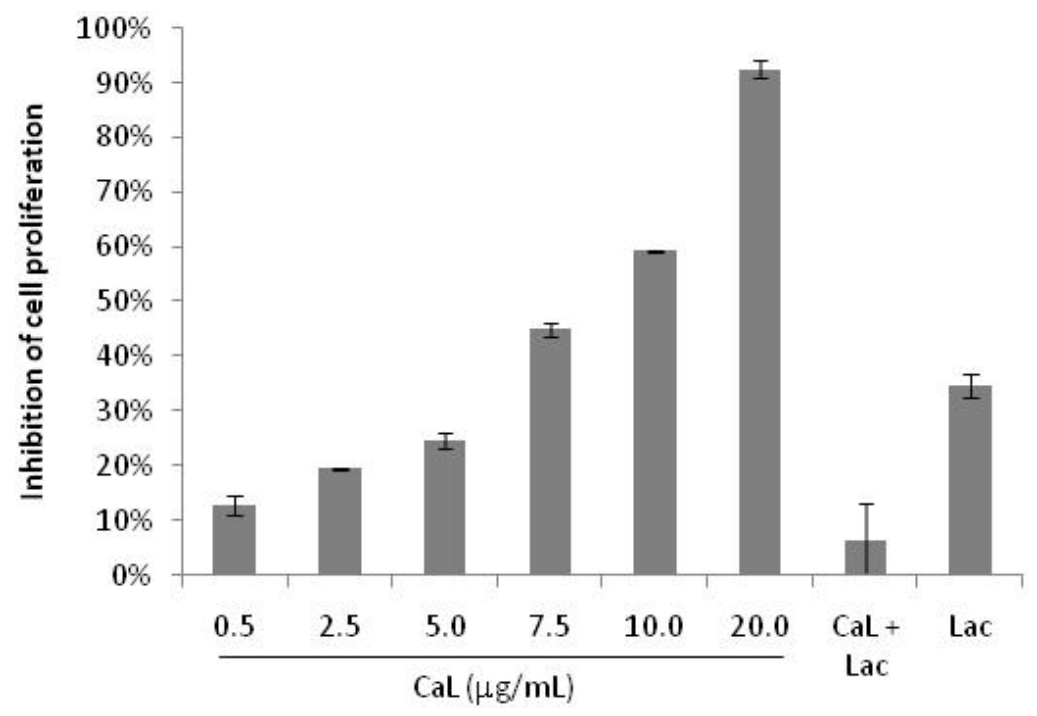

\subsection{Cytotoxicity on Human Peripheral Blood Cells and Hemolytic Activity of CaL}

To test the CaL toxicity against normal cells, the lectin was incubated with erythrocytes and peripheral blood cells, using bovine serum albumin as control. CaL did not show cytotoxicity against human peripheral blood cells when evaluated in blood cell counter and flow cytometry (Figure 3) based on two concentrations: $10 \mu \mathrm{g} / \mathrm{mL}$ and $20 \mu \mathrm{g} / \mathrm{mL}$ (corresponding to one and two times its $\mathrm{IC}_{50}$, respectively). There was also no hemolytic activity for $\mathrm{CaL}$ using $\mathrm{IC}_{50}$ concentration, as seen in the hemolytic assay performed in a 96-well plate (Figure 4).

Figure 3. Flow Cytometry of human peripheral blood in the presence and absence of CaL. (A) Human peripheral blood in absence of $\mathrm{CaL}$; (B) Human peripheral blood in presence of $\mathrm{CaL}, 10 \mu \mathrm{g} / \mathrm{mL}(80.65 \mathrm{nM})$; (C) Human peripheral blood in presence of $\mathrm{CaL}$, $20 \mu \mathrm{g} / \mathrm{mL}(161.29 \mathrm{nM})$.

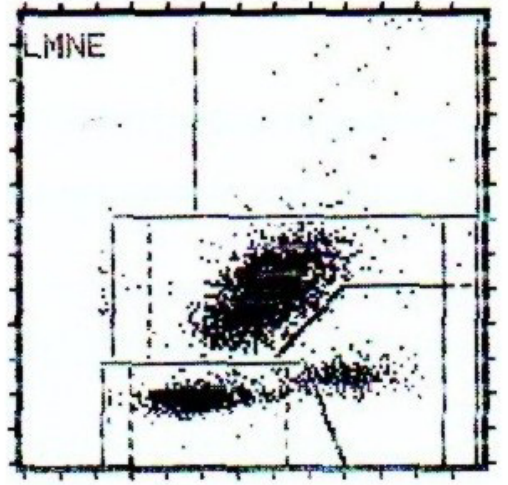

(A)

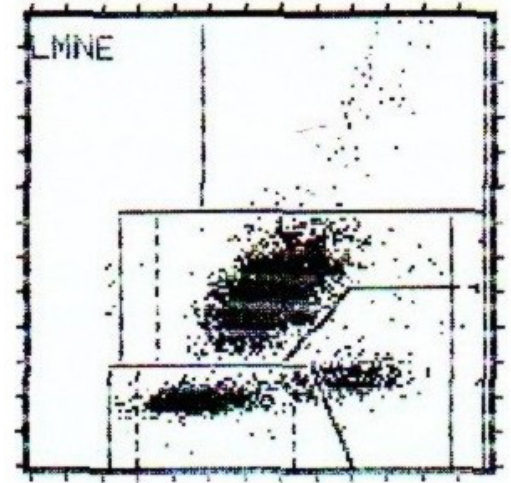

(B)

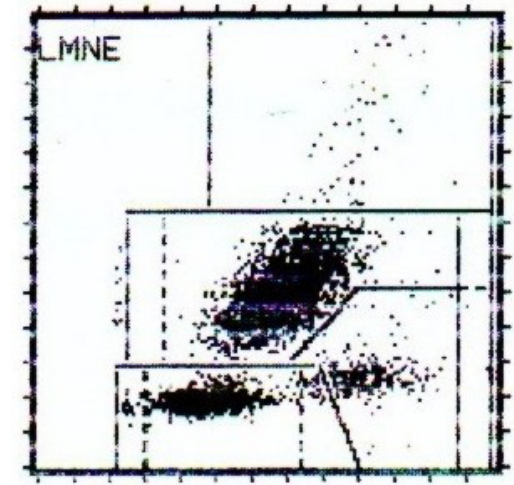

(C) 
Figure 4. Flow Cytometry of human peripheral blood in the presence and absence of CaL. Evaluation of hemolytic effect of $\mathrm{CaL}$ on human red blood cells. Negative and positive controls were used: phosphate buffered saline (PBS) and 1\% Triton X-100, respectively. Results represent the mean $\pm \mathrm{SD}$ of three experiments run in triplicate.

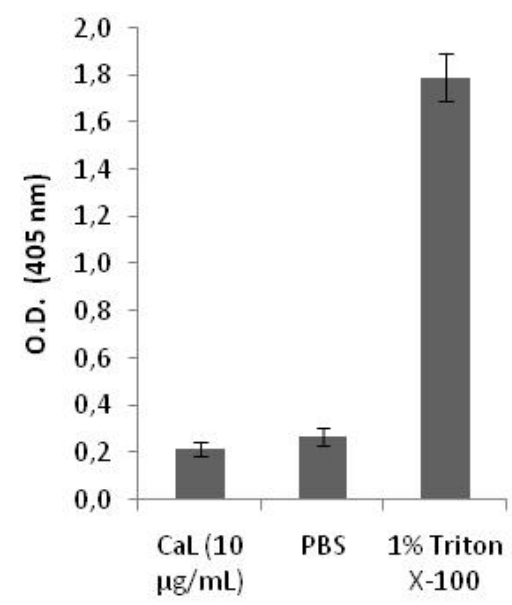

\subsection{Nuclear Morphological Changes Induced by CaL in HeLa Cells}

Nuclear morphological changes were observed by DAPI staining. In the control group, HeLa cells were round in shape and stained homogeneously (Figure 5A). After $24 \mathrm{~h}$ treatment with CaL, blebbing nuclei, picnotic bodies, morphological alterations and granular apoptotic bodies appeared (Figure 5B-D). Markable morphological alterations, including membrane blebbing and nuclear condensation, suggest $\mathrm{CaL}$ induces apoptosis in HeLa cells.

Figure 5. Micrograph of HeLa cells treated with CaL. HeLa cells were incubated with $10 \mu \mathrm{g} / \mathrm{mL}(80.65 \mathrm{nM}) \mathrm{CaL} 24 \mathrm{~h}$ and labeled with DAPI to show nuclear morphology. (A) Control HeLa cells, without CaL; (B-D) HeLa cells treated with CaL, showing nuclear morphological changes such as pyknosis and fragmentation (arrows).

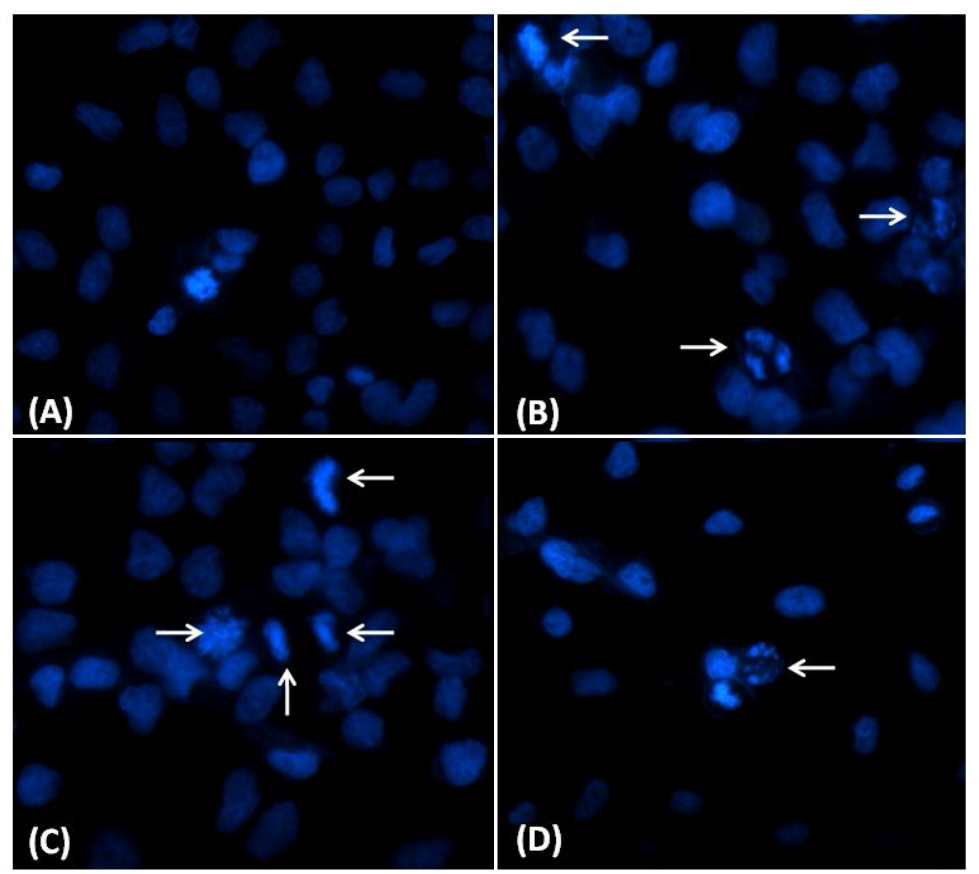




\subsection{Balance between Apoptosis and Necrosis by Double Staining Annexin V-FITC/PI and Cell Cycle Analysis}

To further characterize if CaL-induced HeLa cell death was accomplished by apoptosis or necrosis, the ratios of apoptosis and necrosis in cells were analyzed by flow cytometry after staining of cells with annexin V-FITC/PI. Exposure of $10 \mu \mathrm{g} / \mathrm{mL} \mathrm{CaL} \mathrm{significantly}(p<0.001)$ increased the percentage of cell death in $23.2 \%$ of cells marked only with annexin $\mathrm{V}$ (Figure 6A,B), indicating an early stage of apoptosis, compared to control, with less than $4 \%$ of HeLa cells initiating apoptosis (An+/PI ${ }^{-}$). To evaluate the involvement of caspases in CaL-induced cell death, Z-VAD-FMK (pan-caspase inhibitor) was applied. After $24 \mathrm{~h}$ incubation with CaL, Z-VAD-FMK reduced in 7.7\% cell death (Figure 6C), indicating more than one pathway to apoptosis induced by $\mathrm{CaL}$, both dependent and/or independent of caspases. To minimize the adverse effects of physiological situations stressful to cells, arrest of cell cycle progression can be provided quickly after exposure to stress stimulus. Thus, the effect of the lectin on the distribution of cells in different phases of the cell cycle was analyzed by flow cytometry after staining of cells with PI (Figure 7). Untreated control HeLa cells exhibited normal cell cycle characteristics $\left(\mathrm{G}_{1} / \mathrm{G}_{0}\right.$ e $\mathrm{G}_{2} / \mathrm{M}$ phases). Incubation of cells with $\mathrm{CaL}$ for $24 \mathrm{~h}$ induced cell cycle arrest in $\mathrm{S}$ phase, with $57.6 \%$ of cells in this phase. The presence of Z-VAD-FMK was not able to interfere with cell cycle arrest. Altogether, these results indicate $\mathrm{CaL}$ was able to induce apoptotic cell death in HeLa cells.

Figure 6. Flow Cytometry of HeLa cells treated with annexin V/PI and CaL. The cells were maintained in the presence of $10 \mu \mathrm{g} / \mathrm{mL}$ lectin (with or without Z-VAD-FMK) for $24 \mathrm{~h}$, stained with FITC-annexin V/PI and analyzed by FACScan flow cytometer marked for apoptosis/necrosis. Q1: Annexin V negative/PI positive; Q2: Annexin V/PI positive; Q3: Annexin V positive/PI negative; Q4: Annexin V/PI negative. (A) Control cells without the presence of CaL; (B) Cells incubated with $80.65 \mathrm{nM} \mathrm{CaL}$; (C) Cells incubated with $80.65 \mathrm{nM} \mathrm{CaL}$ along with ZVAD-FMK. One representative chart of two independent experiments for each sample is presented. The analysis of data from flow Cytometry was performed using the FlowJo software [39].

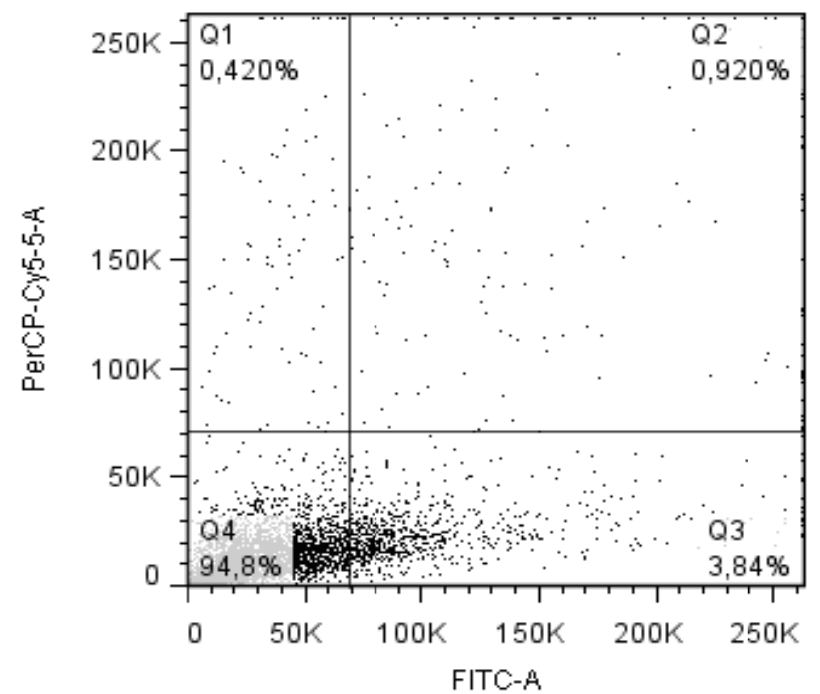

(A)

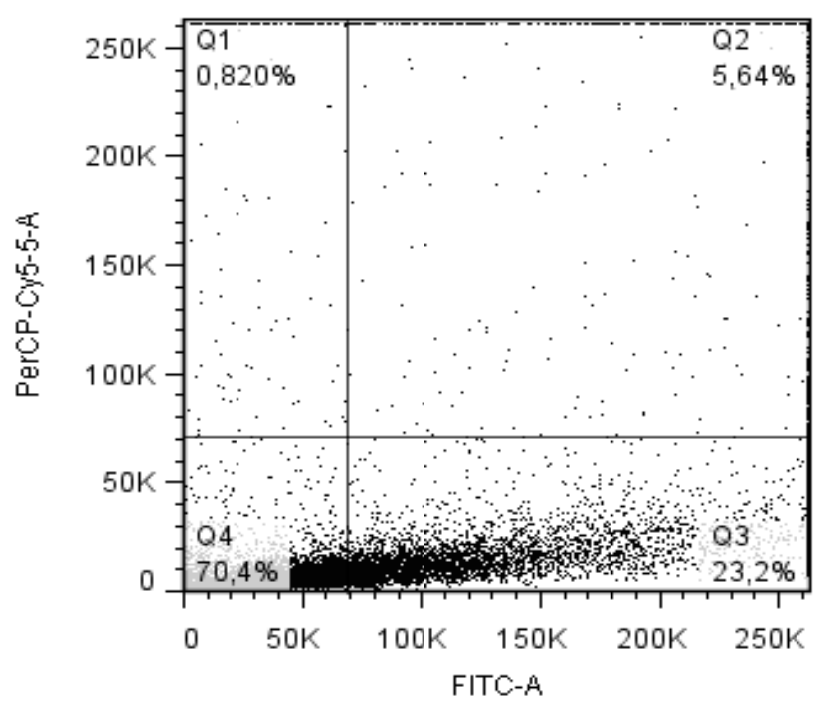

(B) 
Figure 6. Cont.

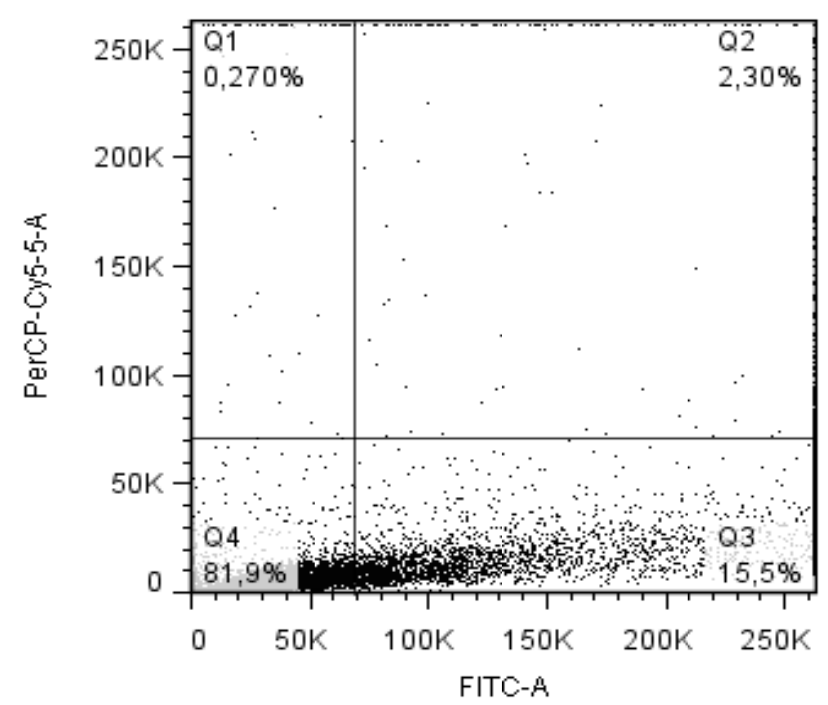

(C)

Figure 7. Evaluation of cell-cycle arrest after exposure to CaL. After $24 \mathrm{~h}$ of treatment with $80.65 \mathrm{nM} \mathrm{CaL}$ (with or without Z-VAD-FMK), HeLa cells were fixed, treated with RNase, stained with PI and analyzed by flow cytometry for assessment of cell cycle distribution. Results represent the mean \pm SD of three experiments run in triplicate. Data analyses for cell cycle arrest were performed using the FlowJo software [39].

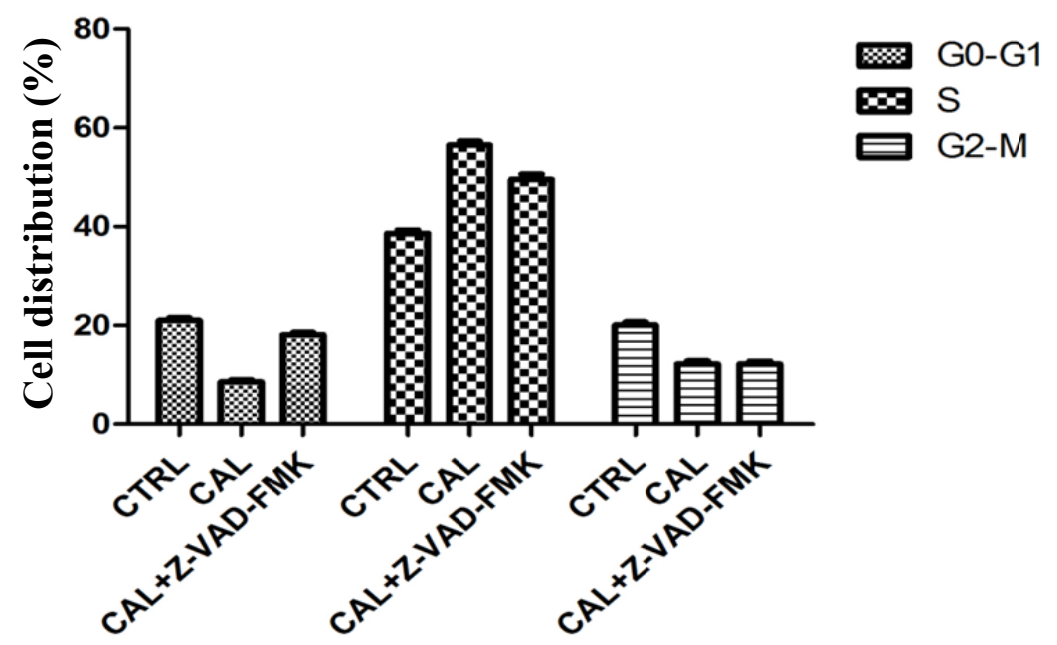

\subsection{CaL Effects in Activation of Proteins Related to Apoptosis in HeLa Cells}

To determine the key proteins involved in inducing cell death in HeLa cells, the Western blotting technique was used. A fixed concentration of CaL $(80.65 \mathrm{nM})$ was incubated with HeLa cells at different incubation times (control, $6 \mathrm{~h}, 12 \mathrm{~h}, 18 \mathrm{~h}$ and $24 \mathrm{~h}$ ) (Figure 8). There was a considerable increase in expression of Bax (pro-apoptotic protein belonging to the Bcl-2 family) and NF- $\mathrm{BB}$ (transcription factor of nuclear factor $\mathrm{\kappa B}$ ) in the form of $105 \mathrm{kDa}$ precursor where this increase was gradual, i.e., in a time-dependent manner. Despite the increase in BAX, anti-apoptotic protein Bcl-2 showed no significant change in expression compared to control (Figure 8B). Western blotting of other proteins related to cell death by apoptosis was also assessed, such as JNK, p-AKT and NF-KB of 
$50 \mathrm{kDa}$ (active form), which showed no change in activation of $\mathrm{p}-\mathrm{AKT}$ in the presence of CaL. However, there was a considerable reduction in the active form of NF- $\kappa \mathrm{B}$ (Figure 8A,B) and a slight increase in JNK activation, over the $24 \mathrm{~h}$ period. These data, together with results obtained in flow cytometry, indicate the toxic effect of $\mathrm{CaL}$ in HeLa cells, suggesting apoptotic cell death through activation of Bax, a pro-apoptotic protein, with mitochondrial membrane permeabilization, acting probably in an intrinsic pathway both dependently and/or independently of caspases.

Figure 8. Immunoblotting of proteins involved in cell death by apoptosis. (A) Protein banding derived from Western Blotting; (B) Graphic expression of BAX, Bcl-2, JNK, $\mathrm{p}-\mathrm{NF} \mathrm{B}(105 \mathrm{kDa}$ and $50 \mathrm{kDa})$ and $\mathrm{p}-\mathrm{AKT}$. One representative immunoblot of three independent experiments is presented. $* * * p<0.001, * * p<0.01, * p<0.05$, compared to control (Student-Newman-Keuls test).

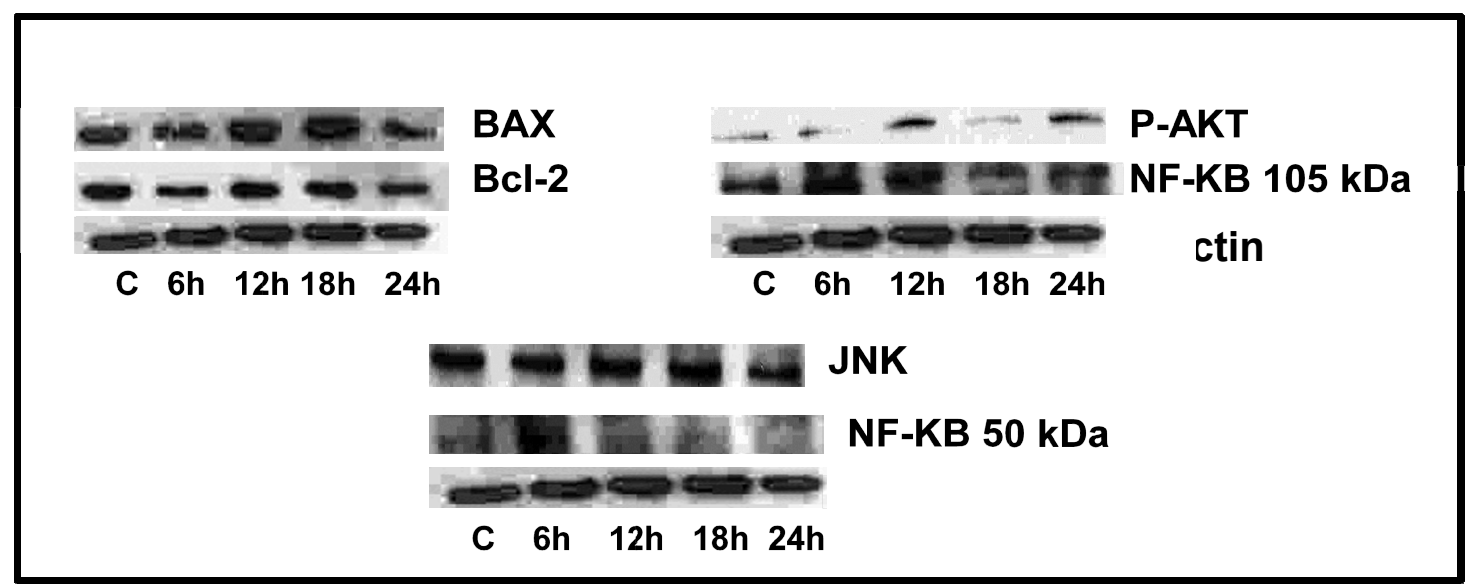

(A)

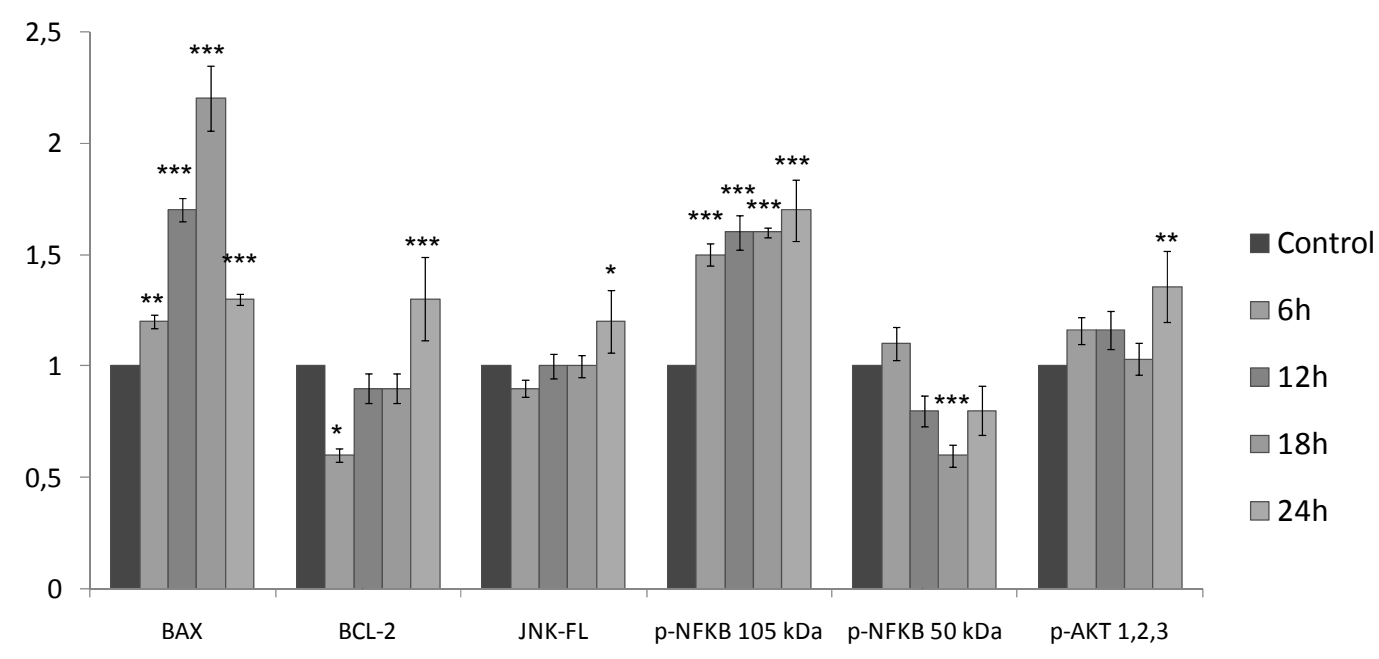

(B)

\section{Discussions}

After a quarter century of advances, cancer research had generated a complex and rich source of knowledge, showing cancer as a disease involving dynamic changes in genome [2]. Several lines of evidence indicate that tumorigenesis in humans is a multistep process, and these steps reflect genetic 
alterations that lead to the progressive transformation of normal human cells to highly malignant derivatives [13].

In recent decades, large numbers of studies have unraveled the pathways of signal transduction in the control of cell death and the molecular machinery responsible for these processes, leading to numerous opportunities for pharmacological intervention and drug design [14]. Among new drugs used in cancer therapy with the potential to interfere with the regulation mechanism of tumor cell growth, natural products have drawn attention as important sources of chemotherapeutic agents and/or chemical and structural models for the development of a multitude of compounds [2,15-18]. Lectins are a class of proteins widely distributed among living organisms, and have attracted attention as potential activators of cell death in tumor tissues by triggering apoptotic signaling cascades [19-26].

The purification procedure of CaL was reproduced according to Medeiros et al. (2010) [27]. Antiproliferative activity of CaL on cell lines HeLa, PC3 and 3T3 was evaluated. CaL was able to induce growth inhibition in all cell lines tested, especially on HeLa cells, in a dose dependent manner, with $\mathrm{IC}_{50}$ of $10 \mu \mathrm{g} / \mathrm{mL}(80.65 \mathrm{nM})$. To prove that the cytotoxic effect of the lectin was not time dependent, tumor cells were exposed, in independent experiments up to $48 \mathrm{~h}$ of treatment with CaL, keeping the profile of cytotoxicity to the cells tested in both test times. Similar results were found for the fungus Agrocybe aegerita lectin (AAL) and the sponge Haliclona cratera with $\mathrm{IC}_{50}$ of $10 \mu \mathrm{g} / \mathrm{mL}$ and $9 \mu \mathrm{g} / \mathrm{mL}$, respectively, against adenocarcinoma cells $[10,28]$. However, CaL had a lower $\mathrm{IC}_{50}$ compared with the lectin Astragalus mongholicus root $(40 \mu \mathrm{g} / \mathrm{mL})$ [29]. In addition to incubation of cells with CaL, its specific inhibitor (lactose $0.1 \mathrm{M}$ ) was tested, either alone or in association with lectin, to assess its antiproliferative activity. There are no reports of antiproliferative activity induced by lactose, so this data is particularly important, since lactose was able to reduce proliferation in approximately $40 \%$ of tumor cells, and stimulate the proliferation of $3 \mathrm{~T} 3$ cells.

$\mathrm{CaL}$ showed no cytotoxic activity, even if incubated with twice its $\mathrm{IC}_{50}(20 \mu \mathrm{g} / \mathrm{mL}$ or $161.3 \mathrm{nM})$ against human erythrocytes or peripheral blood cells. Dresh et al. (2005) [6] analyzed the hemolytic and lectin activity of twenty extracts of sponges from the Atlantic coast of Brazil and found that only two of these extracts showed hemolytic activity, highlighting the potential of lectins as potential candidates for biopharmaceuticals. These results are particularly important, since many traditional chemotherapeutic agents exhibit severe toxicity against normal cells, causing undesirable side effects and thus limiting their application in the clinical field. For this reason there is a clear need for new agents with different mechanisms of action that can be used in direct treatment of these diseases and/or as adjuvant therapy in improving cancer outcomes [15,30].

The visualization of the morphological changes of the HeLa cell line after exposure to CaL was observed by fluorescence microscopy, marked with the dye DAPI, to indicate the activation of cell death by apoptosis. Although these results present strong evidence that the apoptotic pathway is activated, other tests for the analysis of molecular characters are needed to corroborate the results obtained in microscopy. Other studies used the technique of labeling with DAPI for visualization of morphological changes in tumor cells [29,31-34].

The ability to induce apoptosis in CaL was visualized by flow cytometry with annexin V-FITC/PI markup. After $24 \mathrm{~h}$, it was possible to evaluate the induction of apoptosis in HeLa cells by the purified lectin, with approximately $23 \%$ of cells stained only for annexin V. In order to identify the cell death pathway promoted by the lectin, the cells were incubated with $\mathrm{CaL}$ and a general cysteine-protease 
inhibitor capable of binding irreversibly to the catalytic sites of caspases (Z-VAD-FMK). Flow cytometry results indicated that the presence of Z-VAD-FMK reduced the percentage of cells undergoing apoptosis in $7.7 \%$, i.e., $\mathrm{CaL}$ probably induces cell death both dependently and/or independently of caspase activity. Miyoshy and colleagues found the effect of rice bran agglutinin (RBA), wheat germ agglutinin (WGA) and Viscum album agglutinin (VAA) in the induction of apoptosis in U937 cells, proving that RBA induces chromatin condensation, externalization of phosphatidylserine, visualized flow cytometry and DNA fragmentation, and suggests that the mechanism of cell death promoted by RBA is similar to WGA, but different for VAA [23].

Many anti-cancer agents and modifiers of DNA arrest cells in the G0/G1 phase, $\mathrm{S}$ or G2/M by inducing apoptotic cell death [35]. Flow cytometry analysis indicated cell cycle arrest in the $\mathrm{S}$ phase ( $57 \%$ of cells) in HeLa cells after incubation with $\mathrm{CaL}$ for $24 \mathrm{~h}$, both in the presence or absence of cysteine-protease inhibitor Z-VAD-FMK. Cell cycle arrest in S phase is not a common event for lectins. Flow cytometry indicates that fungus Volvariella volvacea lectin (VVL) holds cell proliferation by blocking cell cycle progression in $\mathrm{G} 2 / \mathrm{M}$ phase [36]. A rare reference to this effect was reported for the lectin purified from the roots of Astragalus mongholicus (AMML), which led to imprisonment of HeLa cells in S phase after $24 \mathrm{~h}$ of exposure, to a lesser degree (34-39\% arrest) than $\mathrm{CaL}$ and a higher concentration range (20-40 $\mu \mathrm{g} / \mathrm{mL}$ AMML) than used with $\mathrm{CaL}$ [29]. Imprisonment in S phase was observed in some cell lines treated with sodium ascorbate [37] and an inhibitor of tyrosine kinase Jak-AG490 cells [38]. However, the mechanism responsible for this effect remains unclear.

$\mathrm{CaL}$ findings indicate that, by Western Blot analysis, increased levels of Bax can be observed up to $18 \mathrm{~h}$, decreasing thereafter in $24 \mathrm{~h}$, while not altering the expression levels of Bcl-2. These data suggest that probably $\mathrm{CaL}$ induced mitochondrial membrane permeabilization in HeLa cells, probably activating the apoptotic intrinsic pathway. The levels of anti-apoptotic protein NF- $\mathrm{KB}$ in its inactive form increased progressively with time of exposure to $\mathrm{CaL}$, whereas the activation of Akt remained unchanged. These events promote the activation of apoptosis, since these proteins are involved in the activation of anti-apoptotic members of the Bcl-2 family and IAPS, among other molecules that promote cell survival. The route of apoptotic cell death activated by JNK was not discarded, despite the changes in JNK activation being seen in only $24 \mathrm{~h}$. Future studies may clarify the role of this protein in the antiproliferative mechanism of $\mathrm{CaL}$.

Thus, one can suggest that CaL operates in HeLa cells inducing apoptosis through the activation (not exclusive) of the mitochondrial intrinsic pathway, acting both dependently and/or independently of caspases stimulating mitochondrial membrane permeability and hence, the release of proteins such as cytochrome $c$, AIF and/or EndoG. Several models of cell death involving the participation of initiator/executor caspases, as well as apoptotic cell death independent of caspases have been established, but further studies regarding the participation of other proteins related to this type of cell death are needed to determine the mechanism of action of $\mathrm{CaL}$ in human adenocarcinoma cell (HeLa) apoptosis. 


\section{Experimental Section}

\subsection{Materials}

Papain and bovine trypsin were purchased from Sigma Chemical Co. (St. Louis, MO, USA). Human erythrocytes type A, B and O were donated by the Blood Bank, Hemocentro, Natal, Brazil. Rabbit polyclonal antibodies to human Bax and Bcl-2, rabbit anti-cleaved caspase-3 monoclonal antibody and secondary antibody produced in conjunction with peroxidase goat anti-rabbit were obtained from Cell Signaling Technology (Beverly, MA, USA). Rabbit anti-JNK, anti-p-Akt and anti-NF-אB polyclonal antibodies and peroxidase-conjugated secondary antibody obtained from goat anti-rabbit were obtained from Santa Cruz Biotechnology (Santa Cruz, CA, USA).

\subsection{Preparation of Marine Sponge Cinachyrella apion Lectin (CaL)}

Specimens of the marine sponge Cinachyrella apion were collected on the coast of Santa Rita, Extremoz, RN, Brazil. After collecting, they were transported in ice to the laboratory and stored at $-20{ }^{\circ} \mathrm{C}$ until use. The species was identified by Eduardo Carlos Meduna Hajdu and deposited (Number of collection MNRJ 10142) in Museu Nacional, Rio de Janeiro, Brazil. Lectin from the marine sponge Cinachyrella apion (CaL) was purified essentially as previously described [27]. In short, the lectin was extracted with Tris-HCl buffer, fractionated by acetone precipitation and purified by immunoaffinity and fast protein liquid (FPLC-AKTA purifier) chromatographies.

\subsection{Cell Culture}

HeLa, a human cervical adenocarcinoma cell line, 3T3, an immortalized mouse fibroblast line and PC3, a human prostate adenocarcinoma were obtained from American Type Culture Collection (ATCC, Rockville, MD, USA). Cell lines HeLa and 3T3 were grown in DMEM (Dulbecco's Modified Eagle's Medium), supplemented with $10 \%$ fetal calf serum, adding streptomycin (5000 mg/mL)/penicillin (5000 IU). PC3 cells were grown in a RPMI-1640 medium, supplemented with $10 \%$ fetal bovine serum, and treated with streptomycin $(5000 \mathrm{mg} / \mathrm{mL}) /$ penicillin $(5000 \mathrm{IU})$, kept in a sterile environment at $37{ }^{\circ} \mathrm{C}$ with $5 \% \mathrm{CO}_{2}$ in a humidified atmosphere.

\subsection{Cell Growth Inhibition Assay}

HeLa cells were dispensed in 96-well flat-bottomed microtiter plates (TPP products, Switzerland) at a density of $5 \times 10^{3}$ cells/well. Cells were incubated for 24 and $48 \mathrm{~h}$ with $\mathrm{CaL}$ at given concentrations. The effects of $\mathrm{CaL}$ on cell proliferation were determined using the MTT assay with a plate reader. To assess the effect of carbohydrates on CaL-induced HeLa cell death, the MTT assay was determined as above except that lectin was pre-incubated for an hour with lactose $100 \mathrm{mM}$ (CaL specific inhibitor). The test was performed in triplicate. The measurement of cell proliferation inhibition was carried out in comparison with control containing untreated cells with the lectin purified as follows:

$$
\text { Inhibition rate }=\frac{\left(\mathrm{Abs}_{570} \text { control }+\mathrm{Abs}_{570} \text { sample }\right)}{\mathrm{Abs}_{570} \text { control }} \times 100
$$




\subsection{Cytotoxicity of Human Peripheral Blood Cells and Hemolytic Activity in Vitro}

BSA was used as control at different concentrations ( 5 to $50 \mu \mathrm{g} / \mathrm{mL}$ ) for $15 \min$ at $37{ }^{\circ} \mathrm{C}$ to evaluate possible hematological changes. The cell viability was assessed by blood cell counter (CHCELL 6019-Laborlab). To assess the hemolytic effect of CaL, human erythrocytes were separated from plasma by sedimentation and washed three times with Tris- $\mathrm{HCl} \mathrm{pH} 7.4$ containing $0.01 \mathrm{M} \mathrm{NaCl}$ $0.15 \mathrm{M}$. The same buffer was used to prepare a suspension of $1 \%(\mathrm{v} / \mathrm{v})$ red blood cells and solubilize the samples. $100 \mu \mathrm{L}$ of suspension of red blood cells in $1.5 \mathrm{~mL}$ tubes were incubated with $100 \mu \mathrm{L}$ of sample for $60 \mathrm{~min}$ at room temperature. References to $100 \%$ and $0 \%$ hemolysis were made by incubating a $100 \mu \mathrm{L}$ suspension of red cells with $100 \mu \mathrm{L}$ Triton X-100 1\% (v/v) or $100 \mu \mathrm{L}$ of Tris buffer, respectively. After incubation, the tubes were centrifuged at $3000 \times \mathrm{g}$ for $2 \mathrm{~min}$ and $100 \mu \mathrm{L}$ aliquots of the supernatants were transferred to microtiter plates of 96 wells and analyzed at $405 \mathrm{~nm}$.

\subsection{Evaluation of Indicators of Apoptosis by Incubation with DAPI}

HeLa cell line was seeded on $13 \mathrm{~mm}$ circular coverslips in a 24 -well plate $\left(35.55 \times 10^{4}\right.$ cells/well). After 45 min at $37{ }^{\circ} \mathrm{C}$, DMEM medium supplemented with $10 \%$ FBS was added in a humidified atmosphere of $5 \% \mathrm{CO}_{2}$, to a final volume of $1 \mathrm{~mL}$. $24 \mathrm{~h}$ later, the medium was removed and the cells were deprived for $24 \mathrm{~h}$ with medium without serum. After treatment with medium supplemented with CaL solubilized at a concentration of $10 \mu \mathrm{g} / \mathrm{mL}(80.65 \mathrm{nM})$, cells were washed with cold phosphate buffer (PBS), fixed with $4 \%$ paraformaldehyde for $20 \mathrm{~min}$ and permeabilized in $0.1 \%$ Triton X-100 for about 20 min. Subsequently, cells were washed again with PBS and incubated with DAPI (4',6-diamidino-2-phenylindole) at a concentration of $1 \mathrm{mg} / \mathrm{mL}$ for $30 \mathrm{~min}$, protected from light at room temperature. Cells were visualized by fluorescence microscopy (fluorescence microscope OLYMPUS BX41) using the fluorescence filter 330-380 $\mathrm{nm}$.

\subsection{Annexin V-FITC/PI Double Staining and Analysis by Flow Cytometry}

To evaluate the effects of CaL on cell death, the FITC/annexin V Apoptosis Kit with Dead Cell Annexin FITC and PI, for Flow Cytometry (Invitrogen, Catalog No. V13242), was used. Cells were grown in 6-well plates until they reached confluence of $2 \times 10^{5}$ cells $/ \mathrm{mL}$ with medium without serum and stimulated to exit $\mathrm{G}_{0}$ in the presence of purified lectin solubilized in DMEM, supplemented with $10 \%$ FBS for $24 \mathrm{~h}$. In addition, a negative control was prepared without the presence of CaL, and the action of $\mathrm{CaL}$ incubated with general caspase inhibitor Z-VAD-FMK (carbobenzoxy-valyl-alanylaspartyl-[O-methyl]-fluoromethylketone) $(0.02 \mathrm{mM})$ was also tested to confirm the mechanism of action by which the lectin induces cell death. After exposure to a concentration of $10 \mu \mathrm{g} / \mathrm{mL}(80.65 \mathrm{nM})$ of CaL for $24 \mathrm{~h}$, HeLa cells were trypsinized, collected and washed with cold PBS. The supernatant was discarded and the cells were resuspended in $200 \mu \mathrm{L}$ of $1 \mathrm{X}$ Binding Buffer. $5 \mu \mathrm{L}$ of annexin V-FITC and $1 \mu \mathrm{L}$ of PI solution $(100 \mu \mathrm{g} / \mathrm{mL})$ were added in a $100 \mu \mathrm{L}$ cell suspension. The cells were incubated for $15 \mathrm{~min}$ under room temperature and kept under light protection. After the incubation period, $400 \mu \mathrm{L}$ of binding buffer for annexin V $1 \mathrm{X}$ was added and cells were analyzed by flow cytometry (flow cytometer FASCANTO II, BD Biosciences), measuring the fluorescence emission at 530-575 $\mathrm{nm}$ for annexin V and 630-22 nm for PI. For data analysis, FlowJo software [39] was used. 


\subsection{Cell Cycle Analysis}

HeLa cells were washed with cold PBS and the supernatant was discarded. The pellet with cells was then incubated with $2 \%$ paraformaldehyde, washed with cold PBS and permeabilized with $0.01 \%$ saponin for $15 \mathrm{~min}$. After this procedure, the cells were incubated with $10 \mu \mathrm{L}$ of RNase $(4 \mathrm{mg} / \mathrm{mL})$ at $37{ }^{\circ} \mathrm{C}$ for $30 \mathrm{~min} .5 \mu \mathrm{L}$ of PI solution $(25 \mathrm{mg} / \mathrm{mL})$ along with $200 \mu \mathrm{L}$ of cold PBS to cells were added and taken to the flow cytometer for analysis of cell cycle arrest (630-22 nm). The percentage of apoptotic cells was determined every 20,000 events and graphs obtained in the experiment represent data from three independent experiments. FlowJo software [39] was used for data analysis.

\subsection{Western Blotting}

HeLa cells were plated at a concentration of $9.6 \times 10^{5}$ cells in $75 \mathrm{~mL}$ sterile bottles and incubated for $24 \mathrm{~h}$ for adhesion. A fixed concentration of $10 \mu \mathrm{g} / \mathrm{mL}$ of CaL was added to cells at different times of incubation ( 0 h, 6 h, 12 h, $18 \mathrm{~h}$ and 24 h), washed with cold PBS and removed with $200 \mu \mathrm{L}$ of lysis buffer [50 mM Tris- $\mathrm{HCl}$ (pH 7.4), 1\% Tween 20,0.25\% sodium deoxycholate, $150 \mathrm{mM} \mathrm{NaCl}, 1 \mathrm{mM}$ EGTA, $1 \mathrm{mM} \mathrm{Na} \mathrm{VO}_{4}, 1 \mathrm{mM} \mathrm{NaF}$ and the following protease inhibitors for $2 \mathrm{~h}$ on ice: $1 \mu \mathrm{g} / \mathrm{mL}$ aprotinin, $10 \mu \mathrm{g} / \mathrm{mL}$ and $1 \mathrm{mM}$ leupeptin fluoride of phenylmethanesulfonyl]. Total protein extracts were obtained and a polyacrylamide gel electrophoresis in the presence of SDS was carried out following an established methodology [40]. Protein extracts were resolved and electrophoretically transferred to a polyvinylidene fluoride (PVDF) membrane (Millipore, Bedford, MA, USA) [35]. After transfer, membranes were blocked for non-specific sites with blocking buffer [1\% skim milk or $2 \%$ fetal bovine serum (BSA) in Tris-buffered saline (TBS) with $0.05 \%$ Tween 20 (TBST)], remaining in this solution for one hour, and then incubated for about $12 \mathrm{~h}$ at $4{ }^{\circ} \mathrm{C}$ with appropriate primary antibody diluted in blocking buffer at a ratio of 1:1000. After washing in TBST, membranes were incubated with anti-rabbit secondary antibody conjugated with peroxidase, diluted 1:2000 in blocking buffer for $1 \mathrm{~h}$. The detection was performed using chemiluminescence [41].

\subsection{Statistical Analysis}

All data represent at least three independent experiments and were expressed as mean $\pm \mathrm{SD}$ of triplicates, except were otherwise noted. Differences between groups were compared by the Student-Newman-Keuls or Tukey test, used to show some similarities found by ANOVA. Differences were considered significant when $p$ value was less than 0.05 . Statistical data were analyzed by GraphPad InStat 3.05 [42].

\section{Conclusion}

A lectin was purified from the sponge Cinachyrella apion $(\mathrm{CaL})$ and showed preferential binding activity for type A erythrocytes, treated with papain, despite the presence of divalent ions. The hemagglutinating activity of $\mathrm{CaL}$ was strongly inhibited by disaccharide lactose. $\mathrm{CaL}$ showed no hemolytic or toxicity activity against peripheral blood cells at concentrations of $\mathrm{IC}_{50}$. In addition, this lectin showed high antiproliferative potential against tumor cell lines tested, especially in HeLa cells, acting in a dose-dependent manner. These results indicate that $\mathrm{CaL}$ induces apoptotic cell death in 
HeLa cells, probably by activating the mitochondrial intrinsic pathway, by both pathways, dependent and/or independent of caspases, stimulating mitochondrial membrane permeabilization and promoting the release of cytochrome c, AIF and/or endonuclease G.

\section{Acknowledgments}

The authors acknowledge the support of the Conselho Nacional de Desenvolvimento Científico e Tecnológico (CNPq) and Coordenação de Aperfeiçoamento de Pessoal de Nível Superior (CAPES). The authors thank the Hemonorte, Natal, RN, Brazil, for the generous blood bag donation.

\section{References}

1. Hanahan, D.; Weinberg, R.A. The hallmarks of cancer. Cell 2000, 100, 57-70.

2. Clardy, J.; Walsh, C. Lessons from natural molecules. Nature 2004, 432, 829-837.

3. Hatakeyama, T.; Nagatomo, H.; Yamasaki, N. Interaction of the hemolytic lectin CEL-III from the marine invertebrate Cucumaria echinata with the erythrocyte membrane. J. Biol. Chem. 1995, 270, 3560-3564.

4. Muta, T.; Miyata, T.; Misumi, Y.; Tokunaga, F.; Nakamura, T.; Toh, Y.; Ikehara, Y.; Iwanaga, S. Limulus factor $\mathrm{C}$. An endotoxin-sensitive serine protease zymogen with a mosaic structure of complement-like, epidermal growth factor-like, and lectin-like domains. J. Biol. Chem. 1991, 266, 6554-6561.

5. Takagi, T.; Nakamura, A.; Deguchi, R.; Kyozuka, K. Isolation, characterization, and primary structure of three major proteins obtained from Mytilus edulis sperm. J. Biochem. 1994, 116, 598-605.

6. Giga, Y.; Ikai, A.; Takahashi, K. The complete amino acid sequence of echinoidin, a lectin from the coelomic fluid of the sea urchin Anthocidaris crassispina. Homologies with mammalian and insect lectins. J. Biol. Chem. 1987, 262, 6197-6203.

7. Atta, A.M.; Barralnetto, M.; Peixinho, S.; Sousaatta, M.L.B. Isolation and functional-characterization of a mitogenic lectin from the marine sponge cinachyrella-alloclada. Braz. J. Med. Biol. Res. 1989, 22, 379-385.

8. Bretting, H.; Donadey, C.; Vacelet, J.; Jacobs, G. Investigations on the occurrence of lectins in marine sponges with special regard to some species of the family axinellidae. Comp. Biochem. Physiol. B Biochem. Mol. Biol. 1981, 70, 69-76.

9. Engel, M.; Bachmann, M.; Schroder, H.C.; Rinkevich, B.; Kljajic, Z.; Uhlenbruck, G.; Muller, W.E.G. A novel galactose-specific and arabinose-specific lectin from the sponge pellina-semitubulosa-Isolation, characterization and immunobiological properties. Biochimie 1992, 74, 527-537.

10. Pajic, I.; Kljajic, Z.; Dogovic, N.; Sladic, D.; Juranic, Z.; Gasic, M.J. A novel lectin from the sponge Haliclona cratera: Isolation, characterization and biological activity. Comp. Biochem. Physiol. C Toxicol. Pharmacol. 2002, 132, 213-221.

11. Xiong, C.N.; Li, W.; Liu, H.; Zhang, W.; Dou, J.L.; Bai, X.F.; Du, Y.G.; Ma, X.J. A normal mucin-binding lectin from the sponge Craniella australiensis. Comp. Biochem. Physiol. C Toxicol. Pharmacol. 2006, 143, 9-16. 
12. Queiroz, A.F.S.; Silva, R.A.; Moura, R.M.; Dreyfuss, J.L.; Paredes-Gamero, E.J.; Souza, A.C.S.; Tersariol, I.L.S.; Santos, E.A.; Nader, H.B.; Justo, G.Z.; et al. Growth inhibitory activity of a novel lectin from Cliona varians against K562 human erythroleukemia cells. Cancer Chemother. Pharmacol. 2009, 63, 1023-1033.

13. Renan, M.J. How many mutations are required for tumorigenesis? Implications from human cancer data. Mol. Carcinog. 1993, 7, 139-146.

14. Green, D.R.; Kroemer, G. Pharmacological manipulation of cell death: Clinical applications in sight? J. Clin. Investig. 2005, 115, 2610-2617.

15. Newman, D.J.; Cragg, G.M. Natural products from marine invertebrates and microbes as modulators of antitumor targets. Curr. Drug Targets 2006, 7, 279-304.

16. Ferreira, C.V.; Justo, G.Z.; Souza, A.C.; Queiroz, K.C.; Zambuzzi, W.F.; Aoyama, H.; Peppelenbosch, M.P. Natural compounds as a source of protein tyrosine phosphatase inhibitors: Application to the rational design of small-molecule derivatives. Biochimie 2006, 88, 1859-1873.

17. Strohl, W.R. The role of natural products in a modern drug discovery program. Drug Discov. Today 2000, 5, 39-41.

18. Justo, G.Z.; Ferreira, C.V. Coagulation and cancer therapy: The potential of natural compounds. Curr. Genomics 2005, 6, 461-469.

19. Bantel, H.; Engels, I.H.; Voelter, W.; Schulze-Osthoff, K.; Wesselborg, S. Mistletoe lectin activates caspase-8/FLICE independently of death receptor signaling and enhances anticancer drug-induced apoptosis. Cancer Res. 1999, 59, 2083-2090.

20. Hajto, T.; Hostanska, K.; Berki, T.; Palinkas, L.; Boldizsar, F.; Nemeth, P. Oncopharmacological perspectives of a plant lectin (viscum album agglutinin-I): Overview of recent results from in vitro experiments and in vivo animal models, and their possible relevance for clinical applications. Evid. Based Complement. Alternat. Med. 2005, 2, 59-67.

21. Kim, Y.A.; Lee, W.H.; Choi, T.H.; Rhee, S.H.; Park, K.Y.; Choi, Y.H. Involvement of p21WAF1/CIP1, pRB, Bax and NF- $\mathrm{BB}$ in induction of growth arrest and apoptosis by resveratrol in human lung carcinoma A549 cells. Int. J. Oncol. 2003, 23, 1143-1149.

22. Lavastre, V.; Pelletier, M.; Saller, R.; Hostanska, K.; Girard, D. Mechanisms involved in spontaneous and Viscum album agglutinin-I-induced human neutrophil apoptosis: Viscum album agglutinin-I accelerates the loss of antiapoptotic Mcl-1 expression and the degradation of cytoskeletal paxillin and vimentin proteins via caspases. J. Immunol. 2002, 168, 1419-1427.

23. Miyoshi, N.; Koyama, Y.; Katsuno, Y.; Hayakawa, S.; Mita, T.; Ohta, T.; Kaji, K.; Isemura, M. Apoptosis induction associated with cell cycle dysregulation by rice bran agglutinin. J. Biochem. 2001, 130, 799-805.

24. Ohba, H.; Moriwaki, S.; Bakalova, R.; Yasuda, S.; Yamasaki, N. Plant-derived abrin-a induces apoptosis in cultured leukemic cell lines by different mechanisms. Toxicol. Appl. Pharmacol. 2004, 195, 182-193.

25. Park, R.; Kim, M.S.; So, H.S.; Jung, B.H.; Moon, S.R.; Chung, S.Y.; Ko, C.B.; Kim, B.R.; Chung, H.T. Activation of c-Jun $N$-terminal kinase 1 (JNK1) in mistletoe lectin II-induced apoptosis of human myeloleukemic U937 cells. Biochem. Pharmacol. 2000, 60, 1685-1691. 
26. Rao, P.V.; Jayaraj, R.; Bhaskar, A.S.; Kumar, O.; Bhattacharya, R.; Saxena, P.; Dash, P.K.; Vijayaraghavan, R. Mechanism of ricin-induced apoptosis in human cervical cancer cells. Biochem. Pharmacol. 2005, 69, 855-865.

27. Medeiros, D.S.; Medeiros, T.L.; Ribeiro, J.K.; Monteiro, N.K.; Migliolo, L.; Uchoa, A.F.; Vasconcelos, I.M.; Oliveira, A.S.; de Sales, M.P.; Santos, E.A. A lactose specific lectin from the sponge Cinachyrella apion: Purification, characterization, $N$-terminal sequences alignment and agglutinating activity on Leishmania promastigotes. Comp. Biochem. Physiol. 2010, 155, 211-216.

28. Zhao, C.; Sun, H.; Tong, X.; Qi, Y. An antitumour lectin from the edible mushroom Agrocybe aegerita. Biochem. J. 2003, 374, 321-327.

29. Yan, Z.; Hang, D.; Guo, C.; Chen, Z. Fate of mesenchymal stem cells transplanted to osteonecrosis of femoral head. J. Orthop. Res. 2009, 27, 442-446.

30. Ren, R. Mechanisms of BCR-ABL in the pathogenesis of chronic myelogenous leukaemia. Nat. Rev. Cancer 2005, 5, 172-183.

31. Priyadarsini, R.V.; Murugan, R.S.; Maitreyi, S.; Ramalingam, K.; Karunagaran, D.; Nagini, S. The flavonoid quercetin induces cell cycle arrest and mitochondria-mediated apoptosis in human cervical cancer (HeLa) cells through p53 induction and NF-кB inhibition. Eur. J. Pharmacol. 2010, 649, 84-91.

32. Ogden, C.A.; deCathelineau, A.; Hoffmann, P.R.; Bratton, D.; Ghebrehiwet, B.; Fadok, V.A.; Henson, P.M. C1q and mannose binding lectin engagement of cell surface calreticulin and CD91 initiates macropinocytosis and uptake of apoptotic cells. J. Exp. Med. 2001, 194, 781-795.

33. Hadari, Y.R.; Arbel-Goren, R.; Levy, Y.; Amsterdam, A.; Alon, R.; Zakut, R.; Zick, Y. Galectin-8 binding to integrins inhibits cell adhesion and induces apoptosis. J. Cell Sci. 2000, 113, 2385-2397.

34. Schwarz, R.E.; Wojciechowicz, D.C.; Picon, A.I.; Schwarz, M.A.; Paty, P.B. Wheatgerm agglutinin-mediated toxicity in pancreatic cancer cells. Br. J. Cancer 1999, 80, 1754-1762.

35. Kessel, D.; Luo, Y. Cells in cryptophycin-induced cell-cycle arrest are susceptible to apoptosis. Cancer Lett. 2000, 151, 25-29.

36. Liua, W.; Ho, J.C.; Ng, T. Suppression of cell cycle progression by a fungal lectin: Activation of cyclin-dependent kinase inhibitors. Biochem. Pharmacol. 2001, 61, 33-37.

37. Lin, S.Y.; Lai, W.W.; Chou, C.C.; Kuo, H.M.; Li, T.M.; Chung, J.G.; Yang, J.H. Sodium ascorbate inhibits growth via the induction of cell cycle arrest and apoptosis in human malignant melanoma A375.S2 cells. Melanoma Res. 2006, 16, 509-519.

38. Fuke, H.; Shiraki, K.; Sugimoto, K.; Tanaka, J.; Beppu, T.; Yoneda, K.; Yamamoto, N.; Ito, K.; Masuya, M.; Takei, Y. Jak inhibitor induces S phase cell-cycle arrest and augments TRAIL-induced apoptosis in human hepatocellular carcinoma cells. Biochem. Biophys. Res. Commun. 2007, 363, 738-744.

39. FlowJo, version 7.6.3; Tree Star, Inc.: Ashland, OR, USA 1997.

40. Laemmli, U.K. Cleavage of structural proteins during the assembly of the head of bacteriophage T4. Nature 1970, 227, 680-685.

41. Ferreira, C.V.; Bos, C.L.; Versteeg, H.H.; Justo, G.Z.; Duran, N.; Peppelenbosch, M.P. Molecular mechanism of violacein-mediated human leukemia cell death. Blood 2004, 104, 1459-1464. 
42. GraphPad InStat, version 3.05 for Windows; GraphPad Software: San Diego, CA, USA, 2000.

Samples Availability: Available from the authors.

(C) 2012 by the authors; licensee MDPI, Basel, Switzerland. This article is an open access article distributed under the terms and conditions of the Creative Commons Attribution license (http://creativecommons.org/licenses/by/3.0/). 